\title{
Characterization of Silter Cheeses Produced in Valley and Alpine Pastures by a Proteomic Approach
}

Giusy Rusco ${ }^{1}$, Anna Natale ${ }^{1}$, Carmen Palermo ${ }^{1,2}$, Stefania Chessa ${ }^{3}$, Donatella Nardiello ${ }^{1,2}$, Anna Maria Caroli ${ }^{4}$, Diego Centonze ${ }^{1,2}$, Aldo $^{\text {Di Luccia }}{ }^{1}$, Barbara ${ }^{1}$ Gatta $^{1^{*}}$

${ }^{1}$ University of Foggia-Department of Agro-Food Sciences and the Environment, via Napoli 25, 71122 Foggia, Italy

${ }^{2}$ University of Foggia, CSRA-Applied Research Services Center, via A. Gramsci 89/91-71122 Foggia (FG), Italy

3Institute of Biology and Biotechnology (IBBA-CNR), Via Einstein-26900 Lodi (LO), Italy

${ }^{4}$ University of Brescia, Department of Molecular and Translational Medicine, Viale Europa 11, 25123 Brescia (BS), Italy

*Corresponding author: Barbara la Gatta, University of Foggia-Department of Agro-Food Sciences and the Environment, via Napoli 25, 71122 Foggia, Italy, Tel: +390881589305; E-mail: barbara.lagatta@unifg.it

Received date: 22 June, 2017; Accepted date: 25 July, 2017; Published date: 04 August, 2017

Copyright: (c) 2017 Rusco G, et al. This is an open-access article distributed under the terms of the Creative Commons Attribution License, which permits unrestricted use, distribution, and reproduction in any medium, provided the original author and source are credited.

\begin{abstract}
Silter is an Italian hard cheese manufactured with milk produced by cows fed at different altitude, valley or alpine pasture. The chemical, rheological and sensory properties of cheeses can be affected by the modification in milk composition due to the breed which at different altitude causes the modification of protein content, $\mathrm{k}-\mathrm{CN}$ glycosylation, plasmin activity, and coagulation properties. The influence of milk plasmin activity on dairy production was investigated in seven Silter cheeses, four produced in the valley and three from alpine mountain, through alkaline urea-polyacrylamide gel electrophoresis; two-dimensional gel electrophoresis coupled to mass spectrometry and image analysis. Results demonstrated that Silter cheese obtained from cows reared in alpine pasture is characterized by a more evident proteolysis, determining high levels of $\beta-C N$ and $\alpha_{s 1}-C N$ fragments. Therefore, the most relevant fragmentation was attributed to a more intense activity of plasmin and to a different dosage of rennet to make up for the reduced coagulation properties of alpine milk.
\end{abstract}

Keywords: Silter cheese; Proteomic study; Plasmin action; Valley milk; Alpine milk

\section{Introduction}

Silter is an Italian hard or semi-hard cheese produced in summer in the Valcamonica area from milk of cows fed with valley or alpine pastures. Silter cheese has an ancient origin, very likely from a word of Celtic origin that means Casera in Italian, corresponding to a ripening room [1]. Silter cheese received EU recognition of protected designation of origin (PDO) with Reg. 2081/92. Silter PDO refers to a half-fat hard cheese made with raw milk from cows fed mainly on fodder from the production area. At least $80 \%$ of the animals must belong to typical alpine breeds-Grigio Alpina, Pezzata Rossa and Bruna-the latter of which must represent at least $60 \%$ of the lactating cows present on each individual farm [2].

The chemical, rheological and sensory properties of cheeses can be affected by the modification in milk composition due to the breeding at different altitudes, as already demonstrated by several authors [3-5], causing the modification of protein content, $\kappa-\mathrm{CN}$ glycosylation, plasmin activity, and coagulation properties.

Bugaud et al. [6] and Buchin et al. [4] found an increase of plasmin and plasminogen in milk of cows grazing at high-alpine pastures with respect to those kept down in the valley, especially under unfavorable feeding and climatic conditions. Differences in texture between the cheeses produced in the two areas were also observed and ascribed to the primary proteolysis, partly due to different amounts of plasmin and plasminogen present in the milk [4]. On the contrary, Coulon et al. [7] and Leiber et al. [8] found that neither alpine feed nor altitude-related hypoxia caused the increase of plasmin or plasminogen in milk, while feeding alpine hay even significantly reduced plasminogen. However, Leiber et al. [8] found that hypoxia is related to reduced milk yield and protein content because of a low metabolic energy from impaired energy availability from the alpine pasture that, consequently, reduces protein synthesis. Energy deficit is also accompanied by low plasma glucose levels [9] that reduce the capacity for protein glycosylation, and then, the degree of glycosylation of $\kappa-\mathrm{CN}$ [8]. The negative influence on rennet coagulation properties of alpine milk was attributed to several factors such as reduced protein content, casein proportions, $\kappa-\mathrm{CN}$ content and degree of glycosylation [8]. Casein proportion can be modified by plasmin, an endogenous protease of milk acting on all caseins (CNs), but especially on $\beta$-CN $[4,10,11]$, producing three $\gamma$-CN, polypeptides known as $\gamma 1$ ( $\beta$ fragment 29-209), $\gamma 2$ (Bfragment 106-209) and $\gamma 3$ ( $\beta$ fragment 108-209). If plasmin proteolysis happens prior to coagulation, the breakdown products are lost with the whey [10,12]. As a consequence, plasmin activity adversely affects rennet coagulation properties [13], cheese-making properties and cheese yield. Thus, an up-regulated plasmin system during alpine grazing, enhancing proteolysis during the ripening of cheeses, could also affect cheese taste either worsening it or contributing to specific flavours [4]. Therefore influence of alpine pastures on the plasmin activity in milk is still debated, but generally accepted.

Exougenous enzymes from calf rennet carry out another important proteolytic activity occurring in cheeses. The major components are chymosin (88-94\% milk clotting activity, MCA, EC 3.4.23.4) and bovine pepsin (EC 3.4.23.1; 6-12\% MCA). The main target of chymosin is the cleavage of the bound $\mathrm{Phe}_{105}-\mathrm{Met}_{106}$ of the $\kappa$-CN, which promote milk coagulation and curd formation. In solution, 
chymosin also acts on both $\alpha_{s 1}-\mathrm{CN}$ and $\beta-\mathrm{CN}$ [14], but in cheese, it appears to hydrolyze mainly $\alpha_{\mathrm{s} 1}-\mathrm{CN}$ [15-17]. The residual chymosin activity in the curd has a considerable impact on the proteolysis of cheese and consequently on its quality.

Therefore, our work aimed to evaluate the differences that occur in Silter cheeses from milk produced by cows reared in Alpine and valley farms. Our study was focused to the identification of the casein fragments, resulting from endogenous and exogenous enzymes activities, mainly chymosin and plasmin, by a proteomic approach. Moreover, we also evaluated the presence of molecular marker to trace cheeses from milk of cow bred at low or high altitude.

\section{Materials and Methods}

\section{Chemicals}

All reagents, for the sample preparation and electrophoresis analysis, were ultra pure grade. Formic acid (FA) $\geq 98 \%$, ammonium bicarbonate, 1,4-dithiothreitol, iodoacetamide, acrylamide/bisacrylamide 30\% solution, urea and Coomassie Brilliant Blue G-250, were from Sigma-Aldrich (St. Louis, MO, USA). Modified trypsin (porcine) and chymotrypsin (bovine) were from Princeton Separations (Adelphia, NJ, USA). Water and acetonitrile (ACN), LC-MS CHROMASOLV $^{\circ}, \geq 99.9 \%$, were from Fluka.

\section{Samples}

Seven Silter cheeses were examined, four of them produced in the valley area and three from alpine mountains. In Figure 1 is reported a schematic process of Silter cheese production according to its PDO disciplinary.

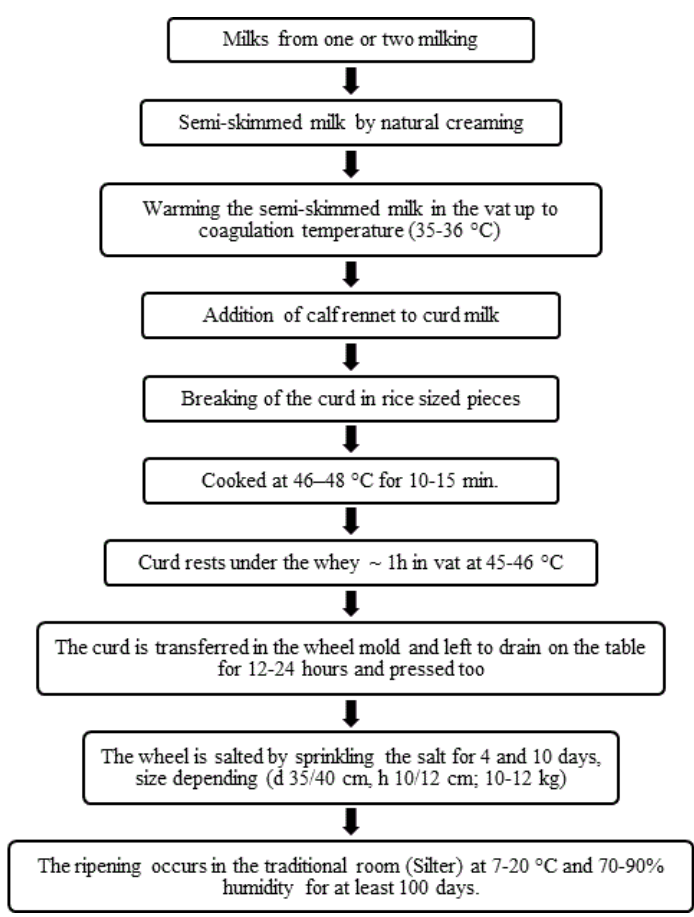

Figure 1: Process of Silter cheese production according to its PDO disciplinary.

\section{Extraction of casein from Silter cheese}

A total of 7 Silter cheese samples were taken after ripening for about 9-10 months. Three samples were produced from cows reared in Alpine sites and four in the valley. Each sample was prepared according to the method of Krause et al. [18], with slight modifications. Cheese $(10 \mathrm{~g})$ was grated, dissolved in $0,5 \mathrm{M}$ sodium citrate $(1: 3 \mathrm{w} / \mathrm{v})$ and shaken for 10 minutes. Then it was heated at $40^{\circ} \mathrm{C}$ for $60 \mathrm{~min}$ and subsequently $2 \mathrm{~N} \mathrm{HCl}$ was added to reach a final $\mathrm{pH}$ of 4.6 , followed by centrifugation at $10.000 \mathrm{xg}$ for $10 \mathrm{~min}$ at $4^{\circ} \mathrm{C}$. The supernatant was discarded and the fat was manually removed. The casein precipitate was washed three times with distilled water performing each time a centrifugation at $10.000 \mathrm{xg}$ for $12 \mathrm{~min}$. Caseins were finally washed two times with cold acetone and recovered for electrophoretic analysis.

\section{Alkaline polyacrylamide gel electrophoresis in the presence of urea (Urea-PAGE)}

Each casein sample $(0.02 \mathrm{~g})$ was dissolved in $1.0 \mathrm{~mL}$ of urea sample buffer $(0,06 \mathrm{M}$ Tris-HCl, $\mathrm{pH}$ 8.6, $8 \mathrm{M}$ urea, traces of bromphenol blue sodium salt) containing $2 \%$ DTT. Samples $(4 \mu \mathrm{L})$ were loaded onto a $7-4 \%$ polyacrylamide gel mini in the presence of $8 \mathrm{M}$ urea. Urea-PAGE analysis was conducted in a discontinuous gel as reported by Andrews [19]. Briefly, electrophoresis was performed with a 7\% Acrylamide/Bisacrylamide separating gel (from a $30 \%$ solution), in a buffer $1,5 \mathrm{M}$ Tris- $\mathrm{HCl} \mathrm{pH} 8.6$ and $8 \mathrm{M}$ urea; the stacking gel was prepared with $4 \%$ Acrylamide/Bis-acrilamyde, (from a $30 \%$ solution) in a buffer $0.5 \mathrm{M}$ Tris- $\mathrm{HCl} \mathrm{pH} 6.8$ and $4 \mathrm{M}$ urea. The electrode buffer was prepared with $0.024 \mathrm{M}$ Tris and $0.19 \mathrm{M}$ glycine and the $\mathrm{pH}$ adjusted to 8.6. Separation was performed using a Mini-PROTEAN Tetra Cell electrophoresis chamber (Bio-Rad Hercules, California, Stati Uniti) at $200 \mathrm{~V}$ for 1 hour.

After the electrophoretic separation the gels were stained with Coomassie Brilliant Blue G-250, according to Candiano et al. [20] and destained with deionized water. The casein fractions were identified according to Mayer [21].

\section{Two-dimensional gel electrophoresis (2-DE)}

An aliquot of $100 \mu \mathrm{L}$ of isoelectric caseins dissolved in a denaturing solution containing $9 \mathrm{M}$ urea to a final concentration of $0.5 \%(\mathrm{w} / \mathrm{v})$, was added with $150 \mu \mathrm{L}$ of DeStreak rehydration solution (GEHealthcare Bio-Sciences, Little Chalfont, U.K.), adding to the solution carrier ampholyte (2\%, pH 3-10) and DTT (1\%), then loaded onto immobilized $\mathrm{pH}$ gradient (IPG) strips, $\mathrm{pH} 3-10,13 \mathrm{~cm}$ long (Biorad, Hercules, California, Stati Uniti). Following rehydration (16 hours), isoelectrofocusing (IEF) was carried out at $20^{\circ} \mathrm{C}$ using an Ettan IPGphor (GE-Healthcare Bio-Sciences, Little Chalfont, U.K.); the voltage was increased stepwise to $8000 \mathrm{~V}$, reaching a total of 13000 Vhrs. Afterwards, the IPG strips were reduced and alkylated using buffers containing $6 \mathrm{M}$ urea, $50 \mathrm{mM} \mathrm{pH} 8.8$ Tris- $\mathrm{HCl}, 2 \% \mathrm{SDS}, 30 \%$ glycerol and $0.002 \%$ BPB, successively supplemented with $1 \%(\mathrm{w} / \mathrm{v})$ DTT and 2.5\% (w/v) iodoacetamide for 20 min each.

The SDS-PAGE separation was performed using $15 \%$ polyacrylamide gels $(15 \times 18 \mathrm{~cm})$ and placed in a Bio-Rad Protean II xi Cell (Bio-Rad, Hercules, California, Stati Uniti) electrophoresis chamber. The electrophoretic separation was performed at $30 \mathrm{~mA}$ for gel at $10^{\circ} \mathrm{C}$. The gels were then stained with Coomassie Brilliant Blue G-250 (Sigma Aldrich, Steinheim, Germany) and digitalized using an 
ImageMaster Scanner (GE-Healthcare Bio-Sciences, Little Chalfont, U.K.).

\section{Protein identification by nano-LC-ESI-IT-MS/MS}

Enzymatic hydrolysis: The protein spots identified by software image analysis were manually excised from the gel and subjected to destaining, reduction, alkylation, washing and, finally, in-gel enzymatic digestion with trypsin/chymotrypsin [22]. Briefly, the gelspot destaining was performed by alternating washing cycles of 15 min each with $50 \mathrm{mM} \mathrm{NH} \mathrm{NHCO}_{3}$ in $50 \%$ aqueous acetonitrile and acetonitrile. Reduction and alkylation were performed by $10 \mathrm{mM}$ dithiotreitol $\left(45 \mathrm{~min}\right.$ at $56^{\circ} \mathrm{C}$ ) and $55 \mathrm{mM}$ iodoacetamide $(30 \mathrm{~min}$ at room temperature in the dark), respectively. After washing cycles with $50 \mathrm{mM}$ ammonium bicarbonate and acetonitrile, the enzymatic mixture trypsin-chymotrypsin in $25 \mathrm{mM}$ ammonium bicarbonate was added at the ratio of 1:50 (w:w). The mixture was incubated overnight at $30^{\circ} \mathrm{C}$, then the enzymatic digestion was stopped by the addition of few microliters of $5 \%$ formic acid. The resulting peptide mixture was stored at $-20^{\circ} \mathrm{C}$ until used.

\section{Liquid Chromatography and Mass Spectrometry}

Chromatographic analysis was performed by a nano-LC apparatus, Ultimate 3000 (Dionex LC-Packings, Amsterdam, The Netherlands) which consisted of an autosampler, a low pressure gradient micropump series, equipped with flow managers, a column thermostat and an UV detector set at $214 \mathrm{~nm}$. The UV flow cell was connected to an ESI-Ion Trap HCTultra ${ }^{\text {Tw }}$ ETD II Basic System (Bruker Daltonics Srl, Bremen, Germany). The nanoLC-ESI-ITMS/MS system was controlled by the softwares Chromeleon CHM-1 (Dionex) and Hystar 2.3 (Bruker Daltonics). A PepMapTM C18 nano trap column $(300 \mu \mathrm{m}$ i.d. $\times 5 \mathrm{~mm}$, $5-\mu \mathrm{m}$ particle size, LC Packings) was used for concentrating and desalting the injected sample. Chromatographic separations were carried out by a PepMap ${ }^{\text {Tw }}$ C18 analytical column $(15 \mathrm{~cm}$ length $\times 75$ $\mu \mathrm{m}$ i.d., $3-\mu \mathrm{m}$ particle size, $100-\mathrm{A}$ pore diameter; LC Packings). The mobile phase consisted of $0.1 \% \mathrm{FA}$ in water (eluent A) and ACN $/ 0.1 \%$ FA in water $(80: 20 \mathrm{v} / \mathrm{v})$ (eluent B). Sample elution through the analytical column was obtained at a flow rate of $0.300 \mu \mathrm{L} / \mathrm{min}$. The optimized elution gradient was the following: $6 \mathrm{~min}$ isocratic step at $96 \% \mathrm{~A}$ and $4 \% \mathrm{~B} ; 29$ min linear gradient to $50 \% \mathrm{~A}$ and $50 \% \mathrm{~B} ; 1 \mathrm{~min}$ linear gradient to $10 \% \mathrm{~A}$ and $90 \% \mathrm{~B} ; 10 \mathrm{~min}$ isocratic step at $10 \% \mathrm{~A}$ and $90 \% \mathrm{~B} ; 1 \mathrm{~min}$ to the initial mobile phase composition $(96 \% \mathrm{~A}$ and $4 \% \mathrm{~B}$ ), at which the system was re-equilibrated for $23 \mathrm{~min}$, for a total run-time of 70 minutes. The micro liter pick-up injection mode was selected by which 1-5 $\mu \mathrm{L}$ of sample were-mixed to the solvent $\mathrm{A}$ to overfill the $5 \mu \mathrm{L}$ sample loop. The gradient elution was combined with a single injection mode, since the opening isocratic step, with trap and analytical column mutually disconnected, allowed an efficient sample pre-concentration and desalting. Therefore, no loading process onto the trap column and no multiple injections for each protein digest were required, prior to separation, which is especially valuable in the analysis of small sample amounts, coming from gel spots. After 6 minutes from the sample injection, the 10-port valve is switched in order to connect on line the trap column with the analytical column. Each gel spot was analyzed in duplicate.

Mass spectrometry analyses were performed by using a high capacity ion trap, coupled to a nano-ESI source for the generation of multiply charged peptide cations, operating in the positive ion mode. The following parameters were set: spray voltage $4.5 \mathrm{kV}$; sheath gas (nitrogen) flow rate $10 \mathrm{~L} / \mathrm{min}$; capillary voltage $1.5 \mathrm{~V}$; and heated capillary temperature $160^{\circ} \mathrm{C}$. A full scan $\mathrm{MS}$ acquisition in the $300-1500 \mathrm{~m} / \mathrm{z}$ range was performed with the acquisition of Base Peak Chromatogram (BPC) and Total Ion Current (TIC) profile. MS/MS analysis by Collision-Induced Dissociation (CID) was performed, using unattended data-dependent acquisition mode and the autoMS/MS event (scan range $100-3000 \mathrm{~m} / \mathrm{z}$ ) was carried out with a number of precursor ions of 3 . The minimal signal required for precursor ion selection was set to an absolute threshold of 10000 .

\section{Data Analysis and Database Search}

Extraction of mass spectra peak-lists from chromatograms, mass annotation, and deconvolution were performed using Data Analysis 4.0 (Bruker Daltonics). The acquired MS and MS/MS datasets were submitted to database searches by Biotools 3.2 (Bruker Daltonics) using the MASCOT search engine (Matrix Science, London, UK). The data analysis files were used to search entries under the Other Mammalia category of SwissProt database, assuming that peptides were monoisotopic and carbamidomethylated at cysteine residues. A maximum number of 2 missed cleavages were allowed and a peptide tolerance of $0.3 \mathrm{Da}$, both for precursor peptide ion and MS/MS tolerance was set, for the window of error for matching the peptide mass values. The option "automatic error tolerant" search was checked to discover unsuspected chemical and post-translational modifications, sequence variants and non-specific cleavage products.

Protein identification was accepted when MASCOT search results delivered scores higher than the identity threshold $(\mathrm{p}<0.05)$ for each sample injection, and with the same protein identification as the top hit for the multiple injection (at least twice) of the same sample. Peptide matches above the identity threshold were submitted to a postdatabase search validation by a manual inspection of the corresponding MS/MS spectra. Therefore, the sequence assignments were cross-checked and only peptides identified in each replicate that satisfied the minimal requirements of ion scores, rank, number and abundances of experimental product ions in the MS/MS spectrum were considered. In order to assess the confidence of peptide identification, the normalized delta scores (e.g. the difference in scores of the 1st and the 2nd ranked peptides, divided by the score of the 1st rank peptide) were examined. MS/MS spectra of matched peptides with an ion score lower than 30 were carefully evaluated, then the corresponding amino acidic sequences were included in the peptide list only if a series of at least 3 continuous fragment ions were observed and if the relevant normalized delta scores was higher than 0.30 .

\section{Results and Discussion}

The proteolysis occurred in Silter cheeses from valley or alpine pastures, was investigated by alkaline Urea-PAGE analysis, twodimensional gel electrophoretic with image analysis followed by singlespot analysis via mass spectrometry.

\section{Alkaline urea-PAGE electrophoresis}

In Figure 2 are shown the electrophoretic patterns of three alpine pasture cheeses (APC) and four valley cheeses (VC). The former were characterized by a lower intensity or absence of $\beta-\mathrm{CN}$ bands and more intense $\gamma$-CNs bands than the latter did. In addition the APC patterns showed more bands related to the $\alpha_{s 1}$ fragments, in particular the $\alpha_{s 1}{ }^{-}$ II-CN bands were more marked than $\alpha_{s 1}$-I-CN ones which were present in all the samples with a comparable band intensity. The formation of these peptides was detected in other cheeses, e.g., in 
Grana cheese [23,24], Abundance cheese [4,6], where the authors essentially identified two $\alpha_{s 1}$ fragments (24-199, $\alpha_{s 1}-\mathrm{I}-\mathrm{CN} ; 24 / 25-169$, $\alpha_{s 1}$-II-CN) as consequence of the chymosin action [15] and the three $\gamma$-CNs originated by plasmin. Marcos et al. [25] comparing proteolysis 0n several cheese varieties reported that, in general, $\alpha_{s 1}$-casein was degraded more extensively than $\beta$-casein. These authors reported that in cheeses in which $\beta$-casein was degraded less extensively (e.g., Parmesan, Emmental, Gruyere and Tilsit), the concentrations of $\gamma 1$ and $\gamma^{2}$-caseins were high, while in cheeses where almost all $\beta$-casein had been degraded (eg. Roquefort), less $\gamma 1$-casein and more $\gamma 2$-and in particular, $\gamma 3$-casein were present, indicating more extensive action of plasmin. Therefore, greater amount of $\gamma-\mathrm{CNs}$ and $\alpha_{s 1}$ fragments observed in APC suggested the occurrence of a more intense hydrolysis at level of plasmin and rennet, respectively.

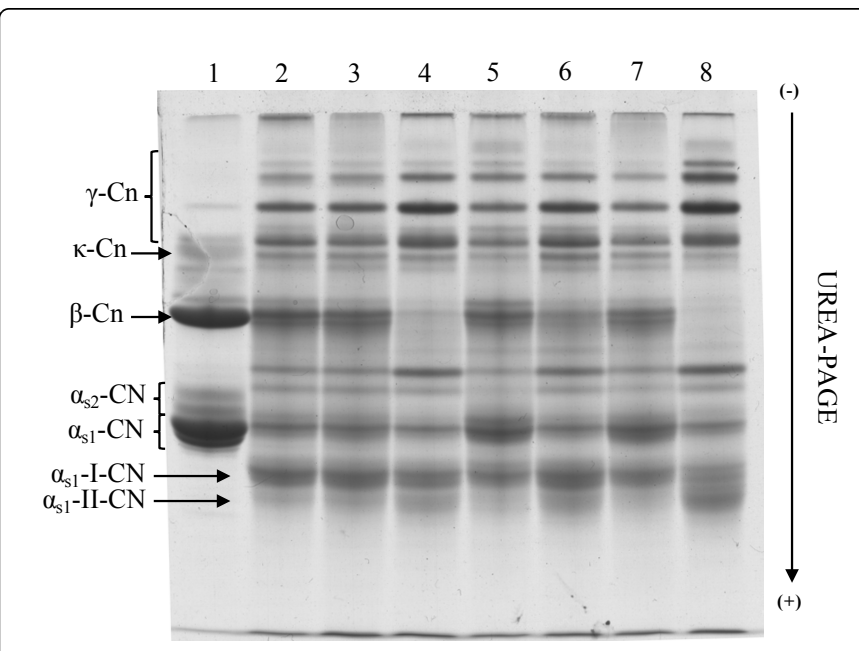

Figure 2: Alkaline discontinuous gel electrophoresis in presence of urea (UREA-PAGE) at $\mathrm{pH} 8.6$, of insoluble caseins at $\mathrm{pH}$ 4.6. The electropherogram shows cow's milk casein in the lane 1; Silter cheese caseins from valley pastures in the lanes 2-3-5-7 and Silter cheese caseins from alpine pastures in the lanes 4-6-8.

\section{Proteomic analysis of Silter produced from Alpine and valley milks}

To better investigate the nature of products from primary proteolysis 2DE gels were fitted out. The typical 2DE maps of Silter cheeses are shown in Figure 3: panel A shows the 2DE map of Silter obtained by alpine milk while panel B shows the 2DE map of Silter obtained by valley milk. The 2DE map of APC showed more spots, which on the basis of spot coordinates (molecular weight and isoelectric point) and tandem mass spectrometry, were identified as fragments of $\alpha_{\mathrm{s} 1}-\mathrm{CN}, \beta-\mathrm{CN}$ and $\kappa-\mathrm{CN}$. In 2DE map of Silter caseins from alpine milk we observed that many spots migrated from the acidic area to the neutral area (spots $1,4,5,7$; and 9; 13,15 and 17; 19; 21 and 23) and few spots were distributed from the neutral to the basic area $(11 ; 25 ; 27)$. This distribution was expected because the caseins have an average acid ( $\mathrm{pH} 4.6)$ isoelectric point ( $\mathrm{pI}$ ) on average of $\mathrm{pH}$ 4.6. In fact proteomic studies of milk proteins $2 \mathrm{DE}$ was performed in the $\mathrm{pH}$ range 4.0-7.0 to reach a better resolution [26,27]. Nevertheless, in the case of cheese it is more useful to analyse casein fraction in the $\mathrm{pH}$ range 3.0-10.0 in order to detect milk proteins and fragments from primary proteolysis of casein. In a recent proteomic study of six months ripened "Caciocavallo cheese" [28], and proteolysis in mozzarella cheese [29], performed in $\mathrm{pH}$ range 3.0-10.0, spreading spots were observed on the entire gel surface. The most of the spots were identified as $\alpha_{\mathrm{s} 1}-\mathrm{CN}$ and $\beta-\mathrm{CN}$ fragments from primary proteolysis due to the enzymatic activity of plasmin and chymosin.

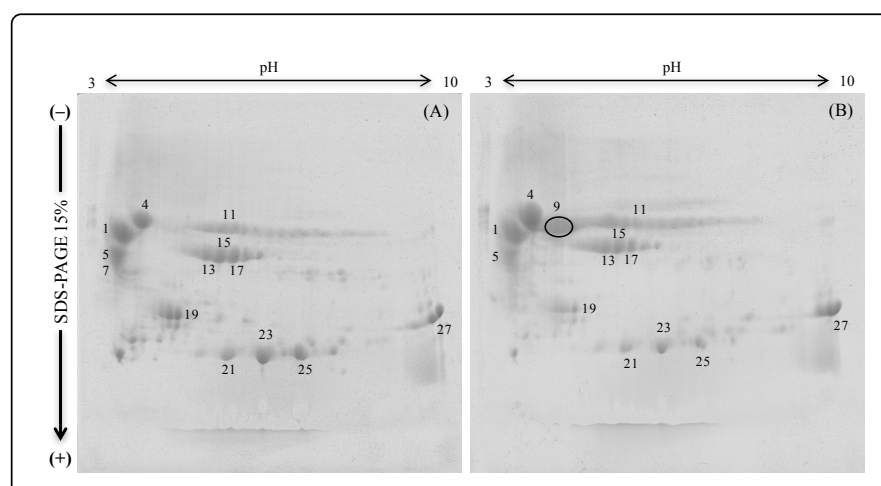

Figure 3: Two-dimensional gel electrophoresis (2DE) was performed in the first dimension by IPG strip 3-10 and in the second dimension, orthogonal to the first, SDS-PAGE was performed using $15 \%$ polyacrylamide gels. The $2 \mathrm{DE}$ maps shows Silter cheese caseins from milk cow fed at alpine (A) and valley (B) pastures. Identification of the numbered spots is reported in Table 1.

A selection of 14 protein spots, identified by image analysis from the reference gel of Figure 3A, were digested with trypsin-chymotrypsin and the resulting peptides were analyzed by tandem MS. As an illustrative example, in Figure 4 the chromatographic separation of peptides from a single gel-spot (No. 19 of Figure 3A) corresponding to $\alpha_{s 1}$-casein is reported. The peaks are reasonably well separated and the mass spectra recorded during the chromatographic run suggests that only limited co-elution occurs. Good results were obtained in terms of protein characterization, with a Mascot score of 140 and a percentage coverage of $47 \%$, associated to the identification of 15 peptides distributed from position 80 to 193 of the mature protein sequence. In addition, partially overlapping amino acidic strings, widely associated to recurring spectra, were observed, thus allowing to increase the chances of obtaining accurate sequence assignments. Figure 5 shows the MS/MS spectrum of the triple charged precursor ion at $\mathrm{m} / \mathrm{z} 596.9$, corresponding to the 15-residue long phosphopeptide KVPQLEIVPNpSAEER (ion score 52), coming from $\alpha_{\mathrm{s} 1}$-casein (spot No. 19). CID fragmentation yielded 13 inter-residue cleavages and 19 ion fragments of $b / y$-type ion series were found with the identification of 6 complementary couples. Therefore, a fragmentation of $68 \%$ was obtained, defined as the number of observed b/y-type fragment ions divided by the theoretical number of fragment ions, e.g. $2(\mathrm{~N}-1)$, where $\mathrm{N}$ is the number of residues for a given sequence. All the gel proteins were identified with scores well above the identity threshold, assigned to progressive numbers and listed in Table 1, associated to their protein code, score and sequence coverage. Moreover, the molecular weight (MW) and the isoelectric point (pI) were calculated on the basis of the total amino acid sequence range associated to the identified peptides. Reasonably, the effective analyzed proteins, extracted from the gel spots, are larger than the estimated amino acid ranges, since missed cleavages could be observed during the enzymatic digestion in proximity of both $\mathrm{N}$ - and C-terminal regions. Obviously, such a situation is valid for all the gel proteins that were simultaneously 
Page 5 of 7

submitted to proteolysis before LC-MS/MS analysis. Hence, we suggested that the amino acidic ranges reported in Table 1 are a good approximation of the effective proteins, also confirmed by the correspondence between the gel-spots localization and the calculated MW and pI values. Our results confirmed that the in-gel digestion with the combined use of trypsin-chymotrypsin provided an accurate identification of cheese proteins from milk produced in alpine farms. Protein bands, corresponding to the main milk proteins, were identified, i.e. $\alpha_{s 1}$ casein (spot N. 1,4,5,7,19), $\alpha_{\mathrm{s} 2}$ casein (spot N. 11), $\beta$ casein (spot N. 9,13,15,17,21,23,25) and k-casein (spot N. 27). Multiple observations of an individual protein that could be isoforms or fragments have been localized in different 2-DE gel regions. A significant correlation between abundance of some polypeptides and ripening process of cheese from milk produced in alpine and valley farms was found. The comparison of $2 \mathrm{DE}$ maps showed the casein fractions and the relevant fragments generated by the enzymatic action of plasmin and chymosin. As a matter of fact, peptides from the Cterminal portion of $\beta$-casein and polypeptidic fragments associated with $\alpha_{s 1}$-casein at different intensity were found in several protein spots. The 2DE map of Silter cheese from alpine dairy showed a higher number of spots at level of $\gamma$-CN $[\gamma 2 \beta$-casein (106-209) and $\gamma 3-\mathrm{CN}, \beta$ casein (108-209)] associated to the spots 21,23 and $25 \mathrm{f}(114-209)$. Moreover, in cheese samples from alpine pasture relatively high levels of fragments of k-casein were also found, such as spot N. 27, f (17-105) that can be identified as para-k-CN.

\begin{tabular}{|c|c|c|c|c|c|c|c|c|c|}
\hline $\begin{array}{l}\text { Gel } \\
\text { Spot }\end{array}$ & Protein & Entry Name & $\begin{array}{l}\text { Protein } \\
\text { Code }\end{array}$ & $\begin{array}{l}\text { MASCOT } \\
\text { Score }\end{array}$ & $\begin{array}{l}\text { No. of } \\
\text { Matched } \\
\text { Peptides }\end{array}$ & $\begin{array}{l}\text { Sequence } \\
\text { Coverage (\%) }\end{array}$ & $\begin{array}{l}\text { Amino } \\
\text { acidic } \\
\text { range }\end{array}$ & MW (Da) & pl \\
\hline 1 & as1-casein & CASA1_BOVIN & P02662 & 291 & 21 & 53 & 24-193 & 19499 & 4.6 \\
\hline 4 & as1-casein & CASA1_BOVIN & P02662 & 434 & 24 & 57 & $4-173$ & 19776 & 4.92 \\
\hline 5 & as1-casein & CASA1_BOVIN & P02662 & 252 & 19 & 56 & 23-193 & 19499 & 4.6 \\
\hline 7 & as1-casein & CASA1_BOVIN & P02662 & 194 & 17 & 52 & $35-193$ & 18279 & 4.58 \\
\hline 19 & as1-casein & CASA1_BOVIN & P02662 & 140 & 15 & 47 & 80-193 & 13298 & 5.14 \\
\hline 11 & as2-casein & CASA2_BOVIN & P02663 & 196 & 13 & 38 & $71-181$ & 13318 & 9.37 \\
\hline 9 & $\beta$-casein & CASB_BOVIN & P02666 & 577 & 17 & 43 & $59-209$ & 16856 & 7.08 \\
\hline 15 & $\beta$-casein & CASB_BOVIN & P02666 & 236 & 18 & 44 & $53-209$ & 17486 & 7.14 \\
\hline 17 & $\beta$-casein & CASB_BOVIN & P02666 & 593 & 18 & 40 & $53-209$ & 17486 & 7.14 \\
\hline 21 & $\beta$-casein & CASB_BOVIN & P02666 & 292 & 15 & 35 & $114-209$ & 10829 & 5.8 \\
\hline 23 & $\beta$-casein & CASB_BOVIN & P02666 & 182 & 18 & 36 & $114-209$ & 10829 & 5.8 \\
\hline 25 & $\beta$-casein & CASB_BOVIN & P02666 & 473 & 16 & 36 & $114-209$ & 10829 & 5.8 \\
\hline 27 & k-casein & CASK_BOVIN & P02668 & 210 & 7 & 39 & $17-105$ & 10273 & 9.76 \\
\hline
\end{tabular}

Table 1: Proteins from Silter cheese identified by MASCOT MS/MS ion searching against Swiss Prot database.

It is noteworthy that in the 2DE map was observed the absence of spot related to $\beta-\mathrm{CN}$ and several spots related to $\gamma-\mathrm{CN}$ fragments, confirming the highest activity of plasmin in Alpine cheese and the highest intensity of the spot identified as para-k-Cn, indicated a higher activity of rennet, probably due to a high amount of rennet used to coagulate Alpine milk.

\section{Image analysis}

The image analysis data are shown in Table 2. In order to establish a relationship between the number of spots and their volume intensities, which showed unbalanced trends in almost all samples, the two datasets were related by computing the ratio between the total number of spots and the total volume intensity, according to Di Luccia et al. [30]. In mathematical terms, this ratio represents a density number defined as spot number density (ds):

$d s=\mathrm{n} / \mathrm{V}_{\mathrm{t}}$

where $\mathrm{n}$ is the total spot number and $\mathrm{V}_{\mathrm{t}}$ is the total volume intensity. Considering that primary proteolysis, which is the first action of endogenous and exogenous (rennet) enzymes on casein fractions, which in turn generate large protein fragments that are still detectable by gel electrophoresis. An increasing of $d s$ should be expected throughout the ripening period. The $d s$ values calculated for the SA and SV are shown in Table 2 and Figure 6 as histograms. A significant difference $(\mathrm{P}<0.05)$ between the $d s$ values of SA and SV cheeses was observed, indicating a more intense proteolysis activity in the SA. These results establish that a more intense action of plasmin and rennin occurred in SA, and probably a higher amount of rennet was used to coagulate milk from alpine pasture to balance time of coagulation and curd firmness [31,32] in alpine milk. These results reconcile the outcomes of Buchin et al. [4], Bugaud et al. [6] that reported more $\beta-\mathrm{CN}$ fragments in milk accounted for higher plasmin activity in alpine and those of Leiber et al. [8] that found a diminution of protein content and $\kappa-\mathrm{CN}$ glycosylation, factors that influence negatively the coagulation aptitude of alpine milks. Moreover, Silter is a hard cheese and during ripening the action of endogenous and exogenous enzymes, including microbial enzymes, could further modify alpine and valley milk raw matter. 


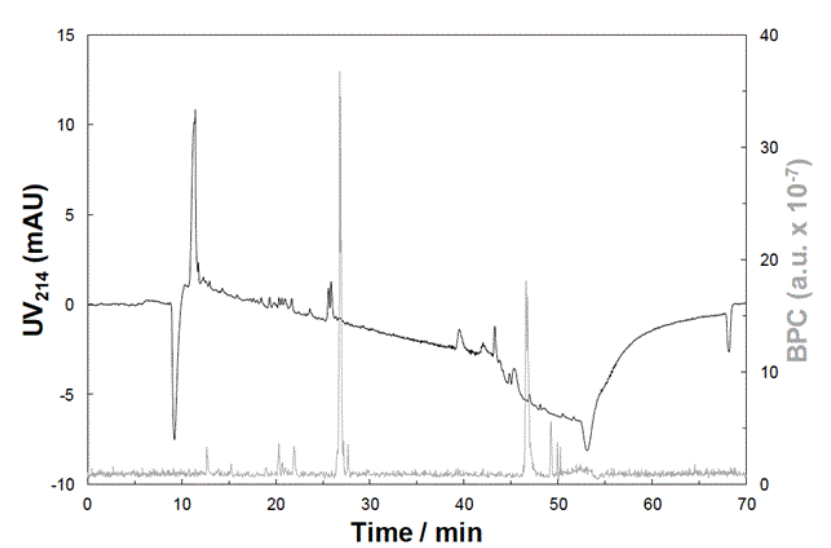

Figure 4: NanoLC-ESI-MS/MS analysis, UV profile (black line) and Base Peak Chromatogram (gray line) of the tryptic-chymotryptic digest from the gel spot No. 19 , identified as $\alpha_{\mathrm{s} 1}$-casein.

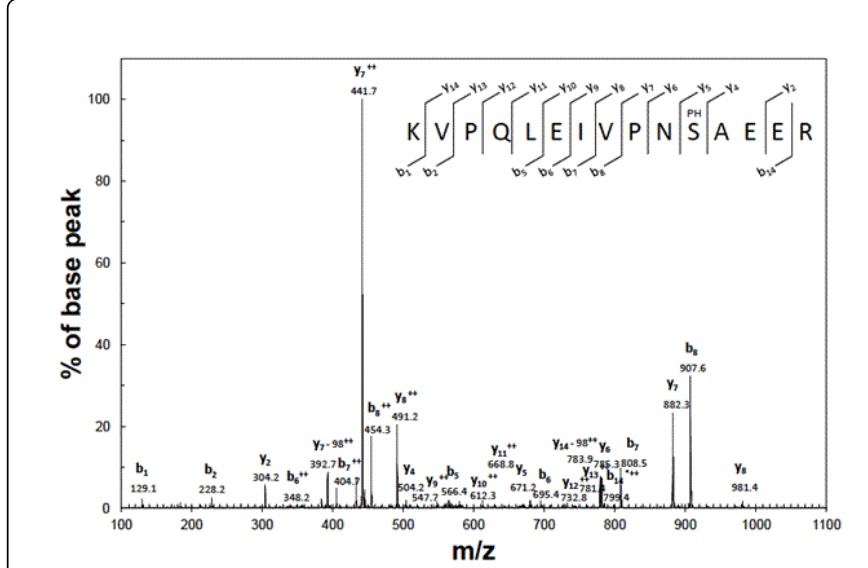

Figure 5: MS/MS spectrum of the triple charged ion at m/z 596.9 from the phosphopeptide KVPQLEIVPNpSAEER of $\alpha_{s 1}$-casein (spot No. 19).

\begin{tabular}{|l|l|l|l|}
\hline Samples & Number of total spot $(\mathbf{n s})^{* *}$ & Total volume $\left(\mathbf{V}_{\mathbf{t}}\right)$ & Density spot $\times \mathbf{1 0 3}(d s)^{*}$ \\
\hline SA & $66 \pm 3$ & $17164 \pm 2140$ & $3.85 \pm 0.47$ \\
\hline SV & $42 \pm 7$ & $14916 \pm 2596$ & $2.95 \pm 0.63$ \\
\hline${ }^{*} P<0.05 ;{ }^{* *} P<0.01$ & & \\
\hline
\end{tabular}

Table 2: Number and volume of spots detected by 2-DE gel electrophoresis and image analysis of casein fractions of Silter cheese produced from alpine (SA) and valley (SV) milk.

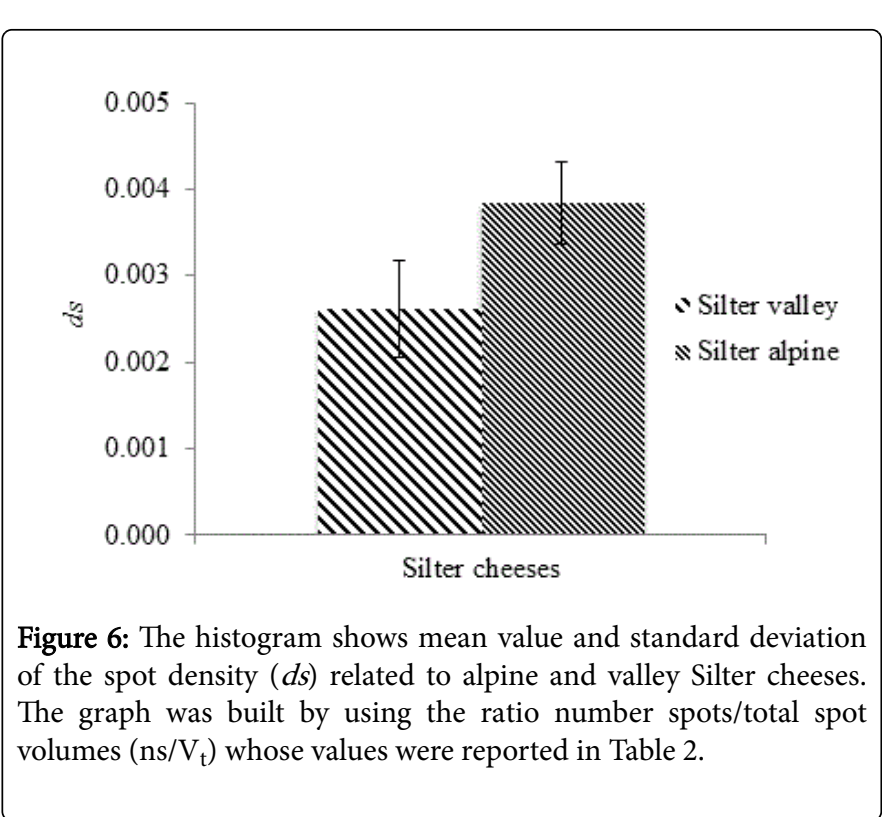

\section{Conclusion}

The proteomic study and image analysis demonstrated unequivocally that Silter cheese obtained by alpine pasture milk (SA) was subjected to a more intense proteolysis than that of Silter cheese manufactured with valley milk (SV). The primary proteolysis occurred in SA produced more $\beta-\mathrm{CN}$ fragments in particular $\gamma-\mathrm{CN}$ ascribable to a higher activity of plasmin in SA samples, according to the preliminary results of the cited literature. In this respect, the notable reduction of $\beta-\mathrm{CN}$ or its absence could be used to trace Alpine cheese. Different dosage of rennet, instead, to make up for a lower coagulation property of alpine milk is probably responsible for the higher concentration of $\alpha_{s 1}$-CN fragments since the alpine location (sojourn) acted unfavourably on renneting properties and cheese yield for a minor content of milk proteins and minor glycosylation of $\kappa-\mathrm{CN}$. Finally, amongst the fragments from primary proteolysis it was remarkable the identification of spots with an approximate $\mathrm{pI} 4,5$ and molecular weight of $15 \mathrm{kDa}$ as a fragment of $\alpha_{\mathrm{s} 1}-\mathrm{CN}$, which, hitherto, not yet well defined by literature in the ripening of cheeses.

\section{References}

1. The Denomination of Protected Origin. Designation of the protected designation of origin.

2. Losio MN, Bozzo G, Galuppini E, Martella V, Bertasi B, et al. (2015) Silter Cheese, a Traditional Italian Dairy Product: A Source of Feasible Probiotic Strains. Int J Food Prop 18: 492-498.

3. Martin B, Coulon JB (1995) Factors of milk production and characteristics of cheeses. 1. Influence of factors of production on the coagulation ability of herd milks. Lait 75: 61-80.

4. Buchin S, Martin B, Dupont D, Bornard A, Achilleos C (1999) Influence of the composition of Alpine highland pasture on the chemical, rheological and sensory properties of cheese. J Dairy Res 66: 579-588. 
5. Leiber F, Kreuzer M, Leuenberger H, Wettstein HR (2006) Contribution of diet type and pasture conditions to the influence of high altitude grazing on intake, performance and composition and renneting properties of the milk of cows. Anim Res 55: 37-53.

6. Bugaud C, Buchin S, Coulon JB, Hauwuy A, Dupont D (2001) Influence of the nature of alpine pastures on plasmin activity, fatty acid and volatile compound composition of milk. Lait 81: 401-414.

7. Coulon JB, Verdier I, Pradel P (1996) Effet du mode de présentation du même fourrage (foin ou herbe pâturée) sur les caractéristiques de fromages de Saint-Nectaire affinés. Lait 76: 479-486.

8. Leiber F, Nigg D, Kunz C, Scheeder MRL, Wettstein HR, et al. (2005) Protein composition, plasmin activity and cheesemaking properties of cows' milk produced at two altitudes from hay of lowland and high-alpine origins. J Dairy Res 72: 65-74.

9. Leiber F, Kreuzer M, Jörg B, Leuenberger H, Wettstein HR (2004) Contribution of altitude and Alpine origin of forage to the influence of Alpine sojourn of cows on intake, nitrogen conversion, metabolic stress and milk synthesis. Anim Sci 78: 451-466.

10. Bastian ED, Brown RJ (1996) Plasmin in milk and dairy products: an update. Int Dairy J 6: 435-457.

11. Fox PF, Singh TK, McSweeney PLH (1994) Proteolysis in cheese during ripening: Biochemistry of Milk Products Andrews AT, Varley J (Eds) Royal Society of Chemistry, Cambridge, UK, pp: 1-13.

12. Mara O, Roupie C, Duffy A, Kelly AL (1998) The curd-forming properties of milk as affected by the action of plasmin. Int Dairy J 8: 807-812.

13. Srinivasan M, Lucey JA (2002) Effects of added plasmin on the formation and rheological properties of rennet-induced skim milk gels. J Dairy Sci 85:1070-1078.

14. Carles C, Ribadeau-Dumas B (1984) Kinetics of action of chymosin (rennin) on some peptide bonds of bovine $\beta$-casein. Biochem 23: 6839-6843.

15. Mulvihill, DM, Fox PF (1979) Proteolytic specificity of chymosin on bovine as1-casein. J Dairy Res 46: 641-651.

16. Mcsweeney PLH, Olson NF, Fox PF, Healy A, Højrupu P (1993) Proteolytic specificity of chymosin on bovine as1-casein. J Dairy Res 60: 401-412.

17. Mulvihill DM, McCarthy A (1993) Relationship between plasmin levels in rennet caseins and proteolytic and rheological changes on storage of cheese analogues made from these caseins. J Dairy Res 60: 431-438.

18. Krause I, Belitz HD, Kaiser KP (1982) Detection of cow's milk in sheep's and goat's milk and cheese by isoelectric focusing on thin layers of polyacrylamide gels containing urea. Z Lebensm Unters Forsch 174: 195-199.
19. Andrews AT (1983) Proteinases in normal bovine milk and their action on caseins. J Dairy Res 50: 45-55.

20. Candiano G, Bruschi M, Musante L, Santucci L, Ghiggeri GM, et al. (2004) Blue silver sensitive colloidal Coomassie G-250 staining for proteome analysis. Elecrophoresis 25: 1327-1333.

21. Mayer HK (2005) Milk species identification in cheese varieties using electrophoretic, chromatographic and PCR techniques. Int Dairy J 15: 595-604.

22. Nardiello D, Palermo C, Natale A, Quinto M, Centonze D (2015) Strategies in protein sequencing and characterization: Multi-enzyme digestion coupled with alternate CID/ETD tandem mass spectrometry. Anal Chim Acta 854: 106-117.

23. Gaiaschi A, Beretta B, Poiesi C, Conti A, Giuffrida MG, et al. (2000) Proteolysis of as-Casein as a Marker of Grana Padano Cheese Ripening. J Dairy Sci 83: 2733-2739.

24. Gaiaschi A, Beretta B, Poiesi C, Conti A, Giuffrida MG, et al. (2001) Proteolysis of $\beta$-Casein as a Marker of Grana Padano Cheese Ripening. J Dairy Sci 84: 60-65.

25. Marcos A, Esteban MA, León F, Fernandez-Salguero J (1979) Electrophoretic patterns of European cheeses: Comparison and quantification. J Dairy Sci 62: 892-900.

26. Jensen HB, Holland JW, Pulsen NA, Larsen B (2012) Milk protein genetic variants and isoforms identified in bovine milk representing extremes in coagulation properties. J Dairy Sci 95: 2891-2903.

27. Holland JW, Deeth HC, Alewood PF (2006) Proteomic analysis of $\kappa-$ casein micro-heterogeneity. Proteomics 4: 743-752.

28. Di Luccia A, Faccia M, Incoronato C, Inglese F, Lamacchia C, et al. (2013) In: Toldrá F, Nollet LML (editors) Cheese Processing: Proteomics in Foods, Principles and Applications New York, pp: 247-259.

29. Petrella G, Pati S, Gagliardi R, Rizzuti A, Mastrorilli P, et al. (2015) Study of proteolysis in river buffalo mozzarella cheese using a proteomics approach. J Dairy Sci 98: 7560-7572.

30. Di Luccia A, Tremonte P, Trani A, Loizzo P, La Gatta B, et al. (2016) Influence of starter cultures and $\mathrm{KCl}$ on some biochemical, microbiological and sensory features of soppressata molisana, an Italian fermented sausage. Eur Food Res Technol 242: 855-867.

31. Garnot P, Corre C (1980) Influence of milk protein concentration on the gelling activity of chymosin and bovine pepsin. J Dairy Res 47: 103-111.

32. Jõudu I, Henno M, Kaart T, Püssa T, Kart O (2008) The effect of milk protein contents on the rennet coagulation properties of milk from individual dairy cows. Int Dairy J 18: 964-967. 